\title{
A personagem-memória e a temporalidade do ser em Um rio chamado tempo, uma casa chamada terra, de Mia Couto
}

\author{
The character-memory and temporality of oneself in \\ Um rio chamado tempo, uma casa chamada terra, Mia Couto
}

\author{
ILSE MARIA DA ROSA VIVIAN \\ Universidade Regional Integrada do Alto Uruguai e das Missões - Frederico Westphalen - Rio Grande do Sul - Brasil
}

-

\begin{abstract}
Resumo: Esse trabalho nasce do desejo de investigar as imagens do homem e suas formas de narrar a si mesmo como remédio à insaciável sede de identidades, cuja temática é, no campo literário, matéria privilegiada pelo gênero romanesco. O presente estudo consiste numa proposta de leitura do romance contemporâneo a partir das estratégias de construção da personagem. A figura ficcional é focalizada, aqui, como fenômeno que, condicionado pela temporalização inerente ao processo de configuração narrativa, põe em evidência a natureza constitutiva do eu, possibilitando ao leitor a formulação de imagens do homem em plena atividade de ser. Tendo em vista os objetivos a serem cumpridos mediante o cruzamento temático entre personagem, identidade e memória, elegi como corpus do trabalho o romance Um rio chamado tempo, uma casa chamada terra (2002), de Mia Couto.
\end{abstract}

Palavras-chave: Narrativa; Personagem; Memória; Identidade

\begin{abstract}
This work was born from the desire to investigate the images of men and their ways of narrating themselves as a remedy to the insatiable thirst of identities, whose theme is the literary field, prime matter by the novelistic genre. The present study is a proposal to reading from the contemporary building strategies romance character. The fictional figure is focused here, as a phenomenon, conditioned by temporality inherent in the narrative setup process, highlights the constitutive nature of oneself, enabling the reader to formulate images of man being in full swing. With the target of achieving recognition itself and thus encompass the meaning of life, oneself appears then, as a subjective dimension articulated by the difficulty to establish truth in our mind. Given the goals formulated by the thematic cross between character, identity and memory, were elected as corpus of work the novels of fiction Um rio chamado tempo, uma casa chamada terra (2002), Mia Couto.
\end{abstract}

Keywords: Narrative; Character; Memory; Identity

Sabe-se que a identidade pessoal reside na memória e que a anulação dessa faculdade implica a idiotia. Pode-se pensar o mesmo do Universo. Sem uma eternidade, sem um espelho delicado e secreto do que passou pelas almas, a história universal é tempo perdido, e nela a nossa história pessoal - que nos envaidece incomodamente.

Jorge Luis Borges ${ }^{1}$

$\mathrm{Da}$ morte ao nascimento. Assim poderia ser resumida a trajetória de vida da narrativa de Mariano, jovem estudante que, ao atravessar o rio, dirige-se à Ilha Luar-do-Chão, sua terra de origem, por ocasião do

\footnotetext{
1 BORGES, Jorge Luis. História da eternidade. Lisboa: Quetzal Editores, 2012.
}

\section{Às margens do rio: o tempo desmoronado}

enterro de seu Avô Dito Mariano. Esse fato origina uma série de experiências, cuja trajetória, desvelando um mosaico de lembranças, leva Mariano ao questionamento da própria identidade:

Há anos que não visito a Ilha. Vejo que se interrogam: eu, quem sou? Desconhecem-me. Mais do que isso: irreconhecem-me. Pois eu, na circunstância, sou um aparente parente. Só o luto nos faz da mesma 
família. Seja eu quem for, esperam de mim tristeza. Mas não este estado de ausência. Não os tranquiliza ver-me tão só, tão despedido de mim. (UR, p. 30)²

Estrangeiro na sua própria terra, cuja tradição preconiza que "todos são irmãos em totalidade" (UR, p. 29), Mariano desloca seu olhar e, pelas perspectivas do outro, observa seu estado de ausência. Pelo contato com cada um, incursiona-se ao passado da família, expondo o contraditório e complexo universo cultural africano, projetado pelas figuras do Avô, da Avó Dulcineusa, de Miserinha, mas, sobretudo, pelas desavenças ideológicas das discrepantes personalidades do pai Fulano e os dois tios, Tio Ultímio e Tio Abstinêncio.

A personagem aparece como lugar instável, cuja imagem vai se formando a partir de seu horizonte, pelo cruzamento das várias identidades postas em seu percurso. A partir disso, multiplicam-se as possibilidades de exposição de seu modo de ser no mundo e de refletir a própria existência.

Por ser no mundo, entendo, com Martin Heidegger (2012, p. 331), que o ser "não só está em geral em um mundo, mas se comporta em sua relação ao mundo segundo um modo de ser predominante"; no mais das vezes, "é tomado por seu mundo". A expressão deve ser compreendida, nesse sentido, como fenômeno que se dá de forma unitária, embora possa ser observado em momentos estruturais constitutivos e de maneiras infinitas.

Na observação da constituição do eu pela construção da personagem, a noção de ser no mundo indica que tomo como pressuposição que "a 'substância' do homem não é o espírito como a síntese de alma e corpo, mas a existência" (HEIDEGGER, 2012, p. 341; grifo do autor), cujo conceito preconiza que o que está em jogo no ser é o entendimento de si mesmo para ser.

A primeira visão do leitor, ao abrir o romance, repousa sobre a percepção de Mariano, que pensa sobre o acontecimento que o obriga a retornar à terra natal, após longos anos de residência na cidade, onde realizava seus estudos. Ao cruzar o rio, linha divisória entre os dois distantes universos nos quais viveu, o urbano e a primitiva Ilha Luar-do-Chão, Mariano, sugestionado pela lembrança da "voz antiga do Avô", pressente a finitude de um tempo:

Vejo esse poente como o desbotar do último sol. A voz antiga do Avô parece dizer-me: depois deste poente não haverá mais dia. E o gesto gasto de Mariano aponta o horizonte: ali onde se afunda o astro é o mpela djambo, o umbigo celeste. A cicatriz tão longe de uma ferida tão dentro: a ausente permanência de quem morreu. No Avô Mariano confirmo: morto amado nunca mais para de morrer. (UR, p. 15)
O sentido paradoxal da morte é responsável pela primeira imagem da personagem e seu modo de habitar o tempo. O leitor tem acesso, antes de tudo, à vivência psicológica e instantânea da personagem através da expressão dos pensamentos e da descrição das sensações manifestadas pela voz que se enuncia do presente.

O significado da imagem da cicatriz, que torna "tão dentro" o que é "tão longe" e que, justamente pela ausência, gera a eterna e permanente presença do "morto amado", apresenta ao leitor um sujeito em pleno movimento no curso da própria vida e que é levado, inevitavelmente, a confrontar-se com a imponente e contraditória condição temporal de ser no mundo.

A figura da morte, que se localiza "ali onde afunda o astro", é proposta pelo prolongamento existente entre o sentimento e o mundo ou, nas palavras de Mariano, entre "o dentro" e o "poente". Nesse contexto, imbricados cosmos e homem, a morte é o signo da face dupla do tempo, que se manifesta tanto pelos efeitos de finitude e ruptura, como de eternidade e permanência.

Essa forma de apresentação, que desnuda o ser pela dialética do interior e exterior, privilegia o aparecimento da personagem como pessoa ${ }^{3}$, uma vez que sua imagem começa a ser erguida pela dinâmica das conjecturas que cria e mantém no decorrer da própria vivência.

Dessa forma, a personagem compõe-se no movimento entre o horizonte do mundo que a cerca e a dimensão de seu espaço íntimo. Ela perderia sua verdade não fosse esse movimento, uma vez que, "frequentemente, é no âmago do ser que o ser é errante. Por vezes, é estando fora de si que o ser experimenta consistências. Por vezes, também, ele está, poderíamos afirmar, encerrado no exterior." (BACHELARD, 2008a, p. 218).

A morte como signo da ruptura com o tempo anterior, explicitada pela voz do narrador, "Vejo esse poente como desbotar do último sol", e a menção à sua eterna e contínua presença, expressa na abertura do romance, "A morte é como o umbigo: o quanto nela existe é a sua cicatriz, a lembrança de uma anterior existência", anunciam, além do fato pontual que desencadeia a crise do eu, a perspectiva existencial da narrativa.

Nesse sentido, a morte figura como uma das dualidades constituintes do ser. A morte que paira, impondo ao ser a finitude da sua condição no mundo, leva o sujeito à reclamação da sua permanência no tempo,

\footnotetext{
2 Em razão do grande número de citações, passo a fazer uso da sigla UR para designar a referência ao romance Um rio chamado tempo, uma casa chamada terra. UR aponta, assim, à edição da Companhia das Letras de 2003, devidamente indicada em Referências.

$3 \mathrm{O}$ conceito é tomado de empréstimo à teoria de Michel Zéraffa, em Pessoa e personagem (2010). A noção de pessoa consiste na visão da personagem como configuração que comporta uma concepção da existência humana aliada à determinada experiência do real.
} 
o que desperta a necessidade da busca por reconhecer-se, única forma de reinscrição no mundo.

$\mathrm{O}$ efeito de instantaneidade, que se cria com a enunciação do presente e o aparecimento do narrador em primeira pessoa, cujo ponto de vista é desprovido do poder de onisciência, faz emergir a imagem da personagem a partir das suas limitadas capacidades de habitar o universo que tem como horizonte, mediante o total desconhecimento de seu destino, com o qual mantém apenas a relação de expectativa e pressentimento.

Tal configuração predispõe ao leitor um lugar. Ao partilhar da dúvida pessoal da personagem sobre si mesma e perante a incerteza do devir, lado a lado com Mariano, o leitor é movido pela ação narrativa a articular os fragmentos da vivência para a composição de uma personalidade.

É claro que a atemporalidade da narrativa que caracteriza o gênero ficcional é mantida, seja com o uso do tempo verbal no pretérito ou no presente, pois o leitor não experimenta como passado o enredo narrado no pretérito, assim como sabe que o presente, uma vez narrado, é acontecimento já experimentado pelo narrador. A respeito desse aspecto, Käte Hamburger, em A lógica da criação literária, afirma que

se o pretérito da ficção narrativa não tem mais a função de passado é porque não é atualizado no sentido temporal. A noção de atualização não é apenas inexata em sua ambiguidade; ela é errônea e enganadora para a designação da estrutura da literatura ficcional, mimética. Significa aqui ficcionalização. E não é contraditório dizer que apesar disso o enredo do romance se desenrola 'agora e aqui', deixando entender assim que não é vivenciado no passado. Pois 'agora e aqui' [...] significa do ponto de vista epistemológico e também linguístico primeiramente o ponto zero do sistema de realidade, que é determinado pelas coordenadas do tempo e do espaço. (HAMBURGER, 1986, p. 68)

Desse modo, seja enunciado a partir do tempo presente ou do tempo passado, é estabelecido o "ponto zero" no momento em que se concretiza o ato da leitura, momento em que leitor e personagem habitam o mesmo sistema de realidade, cuja coordenação origina, em menor ou maior grau, pela intersecção entre a realidade ficcional e a realidade do leitor, a plena, embora sempre móvel, imagem do eu. Nesse sentido, a personagem só começa a existir mesmo no romance quando

experimentamos o enredo de um romance como acontecendo 'agora e aqui', como a experiência de seres fictícios (como diz Aristóteles: atuantes) - o que não significa nada além de nossa experiência de seres hu- manos em sua eu-origo fictícia, à qual se referem todas as possíveis indicações temporais, como as demais indicações. (HAMBURGER, 1986, p. 68; grifos da autora $)^{4}$

A atemporalidade do "ponto zero", que circunscreve leitor e personagem ao mesmo universo temporal do romance, realça o tempo verbal da enunciação narrativa. O relato do eu enunciado do presente, por ser impregnado da forma testemunhal, intensifica alguns efeitos específicos que incidem diretamente na forma como se concebe a pessoa, ou seja, no modo de assimilação e identificação do leitor em relação à personagem e a todos os significados que dela derivam.

Embora o tempo do relato não seja, de forma alguma, substituinte do presente histórico, é porque o presente verbal do narrador aponta para uma experiência pessoal que o ocorrido só pode se referir à pessoa, e, consequentemente, ao lugar e ao tempo projetados por ela, que são o aqui e o agora do passado. Dessa forma, o narrador, ao contar o passado como se fosse presente, trazendo à cena a vivacidade e o dinamismo da vivência, dissolve os limites entre passado e presente, atualizando, com muito mais realidade, os sentidos da própria vida, cuja autenticidade é testemunhada e atestada pelo leitor. Para Hamburger, esse efeito de atualização só pode ser encontrado no relato em primeira pessoa, pois

na lembrança pessoal a representação viva coincide com a impressão de então e, sendo reproduzida na memória, coincide por outro lado com o momento da lembrança e da experiência renovada. O significado e a função exclusivamente existencial da recordação (que ao mais pode ser transferida no sentido metafórico a outros processos espirituais, p. ex. do conhecimento) também se torna válido na iluminação do presente histórico. (HAMBURGER, 1986, p. 71)

O efeito de atualização da forma autobiográfica decorre, sobretudo, do fato de uma experiência de vida ser atribuída a um eu, o qual surge, portanto, como constructo da memória pessoal. A configuração do relato pessoal aprofunda o investimento na personagem pela experiência de seus processos da lembrança, cuja temporalidade aporética induz à constituição do eu pela figuração de seus aspectos existenciais de ser. A ênfase do

\footnotetext{
Käte Hamburger, por considerar que o ponto de vista puramente gramatical não dá conta das situações específicas apresentadas pelo texto ficcional, e, considerando que muitos são inconscientes ao narrador, substitui o termo sujeito-de-enunciação pelo termo epistemológico euorigo. Em concordância com a autora, é preciso observar que "nenhum domínio da linguagem mostra mais nitidamente do que a criação literária que o sistema da sintaxe pode ser logo estreito demais para a vida criativa da linguagem, que tem a sua fonte como tal no domínio mais amplo do pensamento e da imaginação." (HAMBURGER, 1986, p. 48).
} 
discurso recai, assim, com a dimensão temporal com que se configura a narrativa, no eu que conta a própria vida, cuja tessitura só passa a existir pela combinação entre a dialética da mesmidade e da ipseidade desenvolvida no ato narrativo e as diversas formas pelas quais se manifesta a dinâmica da memória.

Dito de outro modo, os tempos verbais linguísticos perdem sua autonomia em relação ao tempo vivido. $\mathrm{Na}$ medida em que o sistema narrativo se articula pela experiência atribuída a um eu, os modos temporais verbais estruturam-se pela dimensão projetada pela ação narrativa. A memória do narrador-personagem constituise como um meio de emancipação da temporalidade da diegese. O sistema de referência temporal, então, para o leitor, tem como base de organização a rede conceitual e simbólica que se forma pela imagem da pessoa que narra.

O título do primeiro capítulo, "Na véspera do tempo", acrescido dos dois parágrafos iniciais, já anuncia ao leitor uma posição no tempo. A configuração narrativa, pela estratégia temporal contida no discurso, indica não apenas que o curso da intriga será regido pelo movimento da consciência da personagem-narradora, a qual, ao cogitar futuros, concebe o hoje como "véspera", mas, sobretudo, que a ação narrativa é orientada pela visão prospectiva. Essa se origina da expectativa da personagem gerada pelo desconhecimento do que possa sobrevir e alterar a vida:

Quem sabe mesmo o Avô não chegasse nunca a ser enterrado? Ficaria sobrado em poeira, nuveado, sem aparência. Sobraria a terra escavada com um vazio sempre vago, na inútil espera do adiado cadáver. Mas não, a morte, essa viagem sem viajante, ali estava a dar-nos destino. E eu, seguindo o rio, eu mais minha intransitiva lágrima. (UR, p. 18)

Mariano, perante o inusitado, sugere possibilidades de desvio ao fluxo do tempo que o arrasta em direção à situação-limite. No curso do impiedoso tempo que flui eternamente como o rio, está, inevitavelmente, a morte a "dar-nos destino". Considerando que "a ideia de um ser-para-o-fim se propõe como o existencial que traz a marca de seu próprio fechamento interno", pois “'findar', no sentido de morrer, constitui a totalidade do ser-aí" (RICOEUR, 2010, v.3, p. 108), a morte é o signo que, ao expor a precariedade da condição humana, tornando-se notável como interrupção das possibilidades de poder$s e r^{5}$, enfatiza a necessidade de exploração das capacidades em busca de atestação da própria vida.

\footnotetext{
5 Utilizo a expressão tendo por base as noções desenvolvidas por Ricoeur, em $O$ percurso do reconhecimento, em que trata da fenomenologia do homem capaz, cujas capacidades decorrem da consciência reflexiva sobre si mesmo, diferença primordial entre o pensamento moderno e o grego, e que está implicada no processo de reconhecimento do si-mesmo. (RICOEUR, 2006, p. 105)
}

Em meio aos pensamentos de Mariano, que cogitam futuros, irrompe a recordação: "Na guerra, eu tivera visões que não queria repetir. Como se essas lembranças viessem de uma parte de mim já morta" (UR, p.27), fazendo submergir o passado e as marcas monumentais da história. Desse modo, a configuração da narrativa, ao imbricar o presente da experiência e sua decorrente expectativa ao passado lembrado, mais do que localizar o leitor e situá-lo no espaço narrativo, realiza a temporalização do eu que narra.

A significação de que se reveste o discurso narrativo apresenta a pessoa como o insólito lugar de íntima implicação entre futuro, presente e passado. Tal como afirma Ricoeur (2010, v. 3, p. 116), na noção de ser já está contida a articulação do tempo que é intrínseca ao projeto primordial da compreensão do si, de modo que "deixar-se advir a si é o fenômeno originário do por-vir". Com base na teoria heideggeriana, Ricoeur diz que
a passagem do futuro ao passado cessa de constituir uma transição extrínseca, porque o ter-sido parece chamado pelo por-vir e, em certo sentido, contido nele. Não existe reconhecimento em geral sem reconhecimento da dívida e de responsabilidade. [...] Pode-se então dizer, resumidamente: "Autenticamente por-vir é o ser-aí autenticamente tendo-sido". Essa abreviação é a do retorno a si inerente a toda tomada de responsabilidade. Assim, o tendo-sido procede do porvir. (RICOEUR, 2010, v.3, p. 117-118; grifos do autor)

Ao "advir a si", portanto, é necessário que se crie o efeito de desmoronamento do tempo. A emissão da voz a partir do tempo presente reforça a expectativa sobre o porvir, uma vez que, com o efeito da instantaneidade do tempo, salienta o discurso da experiência. A expectativa sobre o curso da vida, assim, leva à reabertura do passado, cuja ação consiste no porvir da vida, e da narrativa para o leitor. $\mathrm{O}$ eu da personagem que narra, portanto, aparece conforme são implicadas as formas temporais no movimento da memória. Nesse sentido, como constata Ricoeur (2010, v.3, p. 118), a autenticidade da pessoa é atestada pela identidade dinâmica construída pelo regime da própria história relatada.

Entretanto, o desmoronamento do tempo que faz aparecer o eu pela temporalidade própria da experiência pessoal só pode existir em contraste com a realidade que se apresenta como horizonte do sujeito. Essa realidade é estranha ao protagonista recém-chegado à Ilha Luardo-Chão. A monumentalidade do tempo é expressa por Mariano, entre outras formas, pela oposição ideológica que as figuras do pai Fulano Malta e do Tio Ultímio encerram: 
Meu pai, por exemplo, tinha a alma à flor da pele. Já fora guerrilheiro, revolucionário, oposto à injustiça colonial. Mesmo internado na Ilha, nos meandros do rio Madzimi, meu velho Fulano Malta transpirava o coração em cada gesto. Já meu Tio Ultímio, o mais novo dos três, muito se dava a exibir, alteado e sonoro, pelas ruas da capital. Não frequentara mais a sua ilha natal, ocupado entre os poderes e seus corredores. Nenhum dos irmãos se dava, cada um em individual conformidade. (UR, p. 16)

As referências à história do regime colonial e à decorrente reação anticolonialista, duas formas da ação política da vida coletiva no país, são evocadas no primeiro plano da narrativa pelo viés da história familiar, cuja matéria ressurge a cada incursão de Mariano ao passado. Como alternativa a essa dicotomia política, há a figura do Tio Abstinêncio, cujo nome já indica a opção pelo isolamento e o exílio, "ocupado a trançar lembranças" de um "tempo nunca havido" (UR, p. 17). A descrição do pai e dos tios, logo no início do romance, manifesta, mais uma vez, o lugar periférico, agora de ordem cultural, de onde se enuncia o narrador, posição que revela, mais que qualquer outra, a instável e frágil condição do sujeito em relação ao outro no percurso do reconhecimento:

Quando me dispunha a avançar, o Tio me puxa para trás, quase violento. Ajoelha-se na areia e, com a mão esquerda, desenha um círculo no chão. Junto à margem, o rabisco divide dois mundos - de um lado, a família; do outro, nós, os chegados. Ficam todos assim, parados, à espera. Até que uma onda desfaz o desenho na areia. Olhando a berma do rio, o Tio Abstinêncio profere:

\section{- O Homem trança, o rio destrança.}

Estava escrito o respeito pelo rio, o grande mandador. Acatara-se o costume. Só então Abstinêncio e meu pai avançam para os abraços. Voltando-se para mim, meu tio autoriza:

- Agora, sim, receba os cumprimentos!

Nada demora mais que as cortesias africanas. Saúdam-se os presentes, os idos, os chegados. (UR, p. 26; grifos do autor)

O distanciamento da personagem da vida social e cultural da Ilha aproxima sua situação da posição do leitor. O ritual "que divide dois mundos" explicita a Mariano sua condição de estrangeiro, apesar de se tratar da sua terra natal. Nesse caso, o recém-chegado Mariano, do ponto de vista dos habitantes, é o outro. A estranheza que supostamente possa haver na leitura decorrente da falta de pré-compreensão da tradição africana é amenizada pela semelhante condição da personagem que, como narradora, guia o leitor.

O discurso de Mariano, assim, enunciado da instável e plural posição a que Edward Said denomina "fora do lugar" (SAID, 2004), apresenta-se como a percepção do sujeito que, desconhecendo os códigos de determinado universo social e cultural, por ter sofrido constantes deslocamentos culturais, por transferências geográficas, movimenta-se de formas distintas da lógica que se orienta pelo alinhamento à determinada cultura ou estabilidade de uma tradição. O sujeito "fora do lugar" é impelido a reinventar-se a cada novo contato.

Essa estratégia narrativa elabora a "suspensão dos meus preconceitos", como afirma Gadamer (1998, p. 13) ao se referir aos afrontamentos culturais que compõem a experiência do leitor, uma vez que a minha visão como leitor, num primeiro contato com a tradição africana, acompanha a percepção da personagem, que age e conta em semelhante circunstância.

Tal configuração caracteriza o que chamo de personagem-memória, pois o percurso do reconhecimento, no plano da consciência reflexiva do si-mesmo, constituise pela elucidação dos signos que, na relação de afecção com o universo que lhe é próprio, compõem a própria vida. A capacidade de narrar-se da personagem, cuja dialética sempre implica a ação do leitor a articular os sentidos para a constituição do eu, é, aqui, assim, intensificada pela condição "fora do lugar", da qual decorre o estranhamento à tradição local, postura com a qual se identifica o leitor.

$\mathrm{O}$ contato com o outro, que acontece à medida que Mariano é despertado pelas lembranças do passado familiar, gradualmente diminui a distância afetiva da personagem em relação ao que lhe surge. A religação de Mariano com o lugar acontece, primeiramente, pela recordação da convivência com o Avô Dito Mariano, figura central da aprendizagem na infância:

Para Dito Mariano, a banheira era uma outra espécie de cama. Se havia que se lavar, ele queria a água bem viva, a correnteza do rio, o despenho da chuva. [...] Olhando-o, assim, tão de fato e gravata, me recordo de sua afável temperança. (UR, 2003, p.42)

Aquele era um tempo sem guerra, sem morte. A terra estava aberta a futuros, como uma folha branca em mão de criança. Vovô Mariano era apenas isso: o pai de meu pai. Homem desamarrado, gostoso de rir, falando e sentindo alto. [...] Ter um avô assim era para mim mais que um parentesco. Era um laço de orgulho nas raízes mais antigas, ainda que fosse uma romanteação das minhas origens mas eu, deslocado que estou dos meus, necessitava dessa ligação como quem carece de um Deus. (UR, p.43-44)

Embora Mariano recorde, o faz com a consciência do presente. O sentimento de perda pela morte do avô acompanha e matiza a recordação, que é considerada, pelo narrador, como "uma romanteação" necessária ao "deslocado" eu. A memória, aqui, não transpõe as barreiras do tempo sucessivo da vida da personagem, cumprindo 
apenas a função de efetuação da lembrança com relação aos valores constitutivos do passado. Com esse processo "a ênfase é posta na mesmidade, sem que a característica da identidade pela ipseidade esteja totalmente ausente". (RICOEUR, 2006, p. 123).

Entretanto, pela rememoração das experiências, o leitor é sugestionado a projetar os acontecimentos futuros da narrativa. Ao lembrar-se da infância com o Avô, Mariano afirma que "O velho Mariano sabia: quem parte de um lugar tão pequeno, mesmo que volte, nunca retorna." (UR, p. 45). Dessa forma, cria-se a troca fronteiriça entre as duas perspectivas temporais que movimentam o ato narrativo na constituição do eu: a fala do Avô, embora provinda do quadro estável da lembrança, apresenta-se como elemento gerador de expectativa ao leitor.

Conforme Gilles Deleuze, a memória sob esse signo, denominada memória voluntária, que se estende do presente atual a um passado que foi, ou seja, conservando o passado em si tal como era, deixa escapar ao sujeito o que lhe é essencial: "o ser-em-si do passado". Nesse movimento da memória, o quadro percebido apenas marca uma realidade que pouco aprofunda a reflexão sobre o si-mesmo:

O passado da memória voluntária é, pois, duplamente relativo: relativo ao presente que foi, mas também relativo ao presente com referência ao que é agora passado. O que vale dizer que essa memória não se apodera diretamente do passado: ela o recompõe com os presentes. [...] Dessa maneira, no entanto, a essência do tempo nos escapa, pois se o presente não fosse passado ao mesmo tempo que presente, se o mesmo momento não coexistisse consigo mesmo como presente e passado, ele nunca passaria, nunca um novo presente viria substituí-lo. (DELEUZE, 2010, p. 54)

Esse modo de irrupção do passado, embora não expresse, diretamente, a reflexividade sobre o si-mesmo a ponto de manifestar o "ser em si" projetando-o para além do que já é, engendra o horizonte da personagem, trazendo à cena, por meio de diversos episódios vividos com o outro, a realidade das heranças culturais e toda simbologia que atravessa, pela lembrança, a experiência de Mariano no presente. Pela figura de Juca Sabão, admirado pelo conhecimento da sabedoria local, Mariano relembra importantes ensinamentos adquiridos na Ilha:

Juca Sabão era para mim uma espécie de primeiro professor, para além da minha família. Foi ele que me levou ao rio, me ensinou a nadar, a pescar, me encantou com mil lendas. Como aquela em que, nas noites escuras, as grandes árvores das margens se desenraizam e caminham sobre as águas. Elas se banham como se fossem bichos de guelra. Regressam de madrugada e se reinstalam no devido chão. Juca jurava que era verdade. (UR, p. 61)
O conhecimento do passado de Luar-do-Chão chega a Mariano pela figura do outro. Diante dos relatos do pai Fulano Malta, da Avó Dulcineusa, do Padre Nunes, do médico Amílcar e, sobretudo, das cartas do Avô Dito Mariano, o protagonista testemunha os diversos fragmentos de vidas. As histórias pessoais dos habitantes da Ilha, erigem-se, assim, como signos do passado, cuja compreensão e articulação são necessárias, no nível da intriga, à perseguição dos objetivos impostos pelo Avô à Mariano, e no nível discursivo, à elaboração da própria vida para o reconhecimento de si-mesmo.

A memória individual, carregando em si a capacidade de uma visão histórica, constitui-se como um ponto de vista da visão coletiva. O conjunto heterogêneo de seres que atravessam a trajetória de Mariano, ao mesmo tempo em que realizam o desdobramento do tempo pelo aspecto episódico do relato, singularizam a experiência da personagem, cuja ação é mobilizada pela necessidade de reordenação do universo apresentado como seu horizonte.

A dinâmica da memória, com o desmoronamento do tempo e a consequente temporalização do eu a partir das limitadas capacidades do sujeito, cuja estrutura pressupõe uma visão sobre a experiência do outro, atomiza os constituintes da figuração pela composição esférica e plural de ser no mundo.

\section{O tempo atravessado: $o$ espaço de ser no mundo}

A oposição dos espaços da Ilha e da cidade, elevadas pela descrição do narrador ao estatuto de nação, expressa as profundas diferenças culturais que marcam os dois cenários de trânsito da personagem. A geografia dilacerada do "tão pequeno" país em nada diminui o "infinito" intervalo existente entre as convenções modernas urbanas e a dimensão do espaço cultural das antigas tradições africanas. Mariano, logo que chega à Ilha, manifesta os efeitos de afecção sofridos:

Acordo antes de ser manhã. Uma poeira - será a luz? - infiltra-se para além dos cortinados. Renasce em mim essa estranha sensação que me acontece só em Luar-do-Chão: o ar é uma pele, feita de poros por onde escoa a luz, gota por gota, como um suor solar. (UR, p. 55)

Mas a dualidade do mundo em que se circunscreve Mariano não se restringe ao país, dividido como "nação de duas almas". A Ilha também é cenário contraditório de dupla visão, onde, segundo as palavras do Avô Dito Mariano, "misturavam o respirar da vida e o sopro da morte”. (UR, p. 173). No princípio da narrativa, é exposta a percepção de Mariano sobre a decadência material, causada pelo abandono e descaso político-administrativo, 
e o florescimento dos ritmos naturais e culturais da vida cotidiana que caracterizam o lugar:

Dói-me a Ilha como está, a decadência das casas, a miséria derramada pelas ruas. Mesmo a natureza parece sofrer de mau-olhado. Os capinzais se estendem secos, parece que empalharam o horizonte. À primeira vista, tudo definha. No entanto, mais além, à mão de um olhar, a vida reverbera, cheirosa como um fruto em verão: enxames de crianças atravessam os caminhos, mulheres dançam e cantam, homens falam alto, donos do tempo. (UR, p. 28)

Sob a afecção do olhar atento do protagonista, é descrita a situação paradoxal de um universo marcado pela coexistência da estagnação e decadência material com a intensa e viva atividade humana. O mundo insular, arquetipicamente, é o lugar consagrado ao desenvolvimento espiritual:

La isla es un mundo reducido, una imagen del cosmos completa y perfecta, porque presenta un valor sacro concentrado. La noción se une por ahí a la de templo y de santuario. La isla es simbólicamente un lugar de elección, de ciencia y de paz en medio de la ignorancia y la agitación del mundo profano. Representa un centro primordial, sagrado por definición [...] (CHEVALIER, 1986, p. 596)

Os significados atribuídos à imagem da ilha variam segundo a história das sociedades. Do ponto de vista da literatura moderna, a imagem da ilha tem sido evocada como refúgio "donde la consciencia y la voluntad se unen para escapar a los asaltos de lo inconsciente, contra las olas del océano se busca el socorro de la roca." (CHEVALIER, 1986, p. 596). Entretanto, o horizonte da ilha para onde se volta o olhar de Mariano é bem diferente da imagem desejada por ele e da pressuposta pelo leitor, considerando a inicial maiúscula, anunciada no início do romance. A Ilha constitui-se, depois da incômoda morte não consumada do Avô, como o segundo obstáculo no percurso da personagem.

Mariano é o eleito para conduzir o enterro do Avô. Esse é o motivo de seu retorno à terra natal, mas sua presença somente será efetivada quando, ao desvelar a série de mistérios familiares, o protagonista assimila as antigas tradições e, de forma recíproca, é reconhecido pela comunidade. A promessa que orienta a intriga é justamente a de resgatar e manter as raízes locais, de modo a preservar a continuidade do si mesmo.

O espaço, dessa forma, duplica os efeitos do tempo e exerce um papel preponderante na construção da personagem. No caminho do reconhecimento de si mesmo, Mariano tem sua trajetória marcada pelos signos da composição da Ilha, que se interpõem como obstáculos ou como coadjuvantes ao protagonista. Paralelamente ao espaço público e às figuras monumentais da vida coletiva, é apresentado o universo privado da casa que, como metonímia da Ilha, constitui-se em espaço propício à dialética interior e exterior, movimento constitutivo do ato narrativo que revela a personagem pela dinâmica pessoal e íntima, sem prescindir da expressão de sua condição histórica e cultural.

$\mathrm{Na}$ mesma medida em que a Ilha Luar-do-Chão figura-se como o lugar "primeiro do [nosso] clã, os Malilanes" (UR, p. 18) e contrapõe-se, assim, ao caráter profano da cidade, a "Nyumba-Kaya", como é chamada a casa no dialeto africano, adquire a conotação simbólica da miniatura interna, ideal e completa do cosmos. A casa dos Malilanes, em especial a da infância, é um símbolo fundamental à construção da personagem, uma vez que se apresenta como o espaço vivido mais próprio do sujeito, ou seja, a imagem da casa expõe o ser pela sua habilidade de trânsito entre exterior e intimidade.

A Nyumba-Kaya é o ponto referencial físico central dos acontecimentos e seus conflitos, cuja solução, considerada a (semi)morte do Avô, que "estava em dificuldade de transitação, encravado na fronteira entre os mundos" (UR, p. 41), só pode ser alcançada com a intervenção de Mariano, que é designado pelo Avô para assumir a tarefa de guardião da casa. Semelhante à imagem da Ilha, a casa é descrita por Mariano, à primeira vista, pela sua exuberância:

Por fim, avisto a nossa casa grande, a maior de toda a Ilha. Chamamos-lhe Nyumba-Kaya, para satisfazer familiares do Norte e do Sul. Nyumba é a palavra para nomear "casa" nas línguas nortenhas. Nos idiomas do Sul, casa se diz 'Kaya'. Mesmo ao longe, já se nota que tinham mandado tirar o telhado da sala. É assim, em caso de morte. [...] A casa é um corpo - o tecto é o que separa a cabeça dos altaneiros céus. Sobre mim se abate uma visão que muito se irá repetir: a casa levantando voo, igual ao pássaro que Miserinha apontava na praia. E eu olhando a velha moradia, a nossa Nyumba-Kaya, extinguindo-se nas alturas até não ser mais que nuvem entre nuvens. (UR, p. 28-29)

A percepção da personagem sobre a ruína da casa "extinguindo-se nas alturas" antecipa ao leitor o aprofundamento da crise pessoal. A mistura das línguas para nomear a casa, a remoção do teto para a necessária ligação entre a terra e o céu e a devida "limpeza das cósmicas sujidades" enfatizam, pela imagem, a importância atribuída pela comunidade aos rituais e aos valores culturais herdados. À decadência da casa, portanto, está subjacente "o colapso de todo um modo de viver" (UR, p. 88). Dessa forma, pela simbologia da casa é feita a ligação de sentidos entre a trajetória pessoal do protagonista as questões sociais e históricas de destino coletivo. 
Bachelard, em seus estudos sobre a representação do espaço pela poética, propõe que a polaridade e a ordem do mundo podem ser observadas pelas imagens da casa:

A casa é um corpo de imagens que dão ao homem razões ou ilusões de estabilidade. [...] é imaginada como um ser vertical. Ela se eleva. Ela se diferencia no sentido de sua verticalidade. É um dos apelos à nossa consciência de verticalidade; a casa é imaginada como um ser concentrado. Ela nos leva a uma consciência de centralidade. [...] Nós nos tornaremos sensíveis a essa dupla polaridade vertical da casa se nos tornamos sensíveis à função de habitar a ponto de fazer dela uma réplica imaginária da função de construir. (BACHELARD, 2008a, p. 36-37)

O valor de centralidade expresso pelo espaço poético da casa, que posiciona o sujeito na imensidão do mundo, está intrinsecamente implicado no sistema do mundo ao qual faz referência. Assim, o contraponto à estabilidade, que assegura à consciência a concentração e a ordem, é a extensão indefinida e instável do universo cósmico, sempre pressuposta na espacialidade projetada pelo modo de ser-no-mundo. Dessa forma, a casa é o símbolo ideal para expressar o impacto sofrido pela personagem quando se defronta com o universo da Ilha. De uma perspectiva externa, posição ocupada pela personagem em relação a todo o contexto de Luar-do-Chão, Mariano observa:

A grande casa está defronte a mim, desafiando-me como uma mulher. Uma vez mais matrona e soberana, a Nyumba-Kaya se ergue de encontro ao tempo. Seus antigos fantasmas estão, agora, acrescentados pelo espírito do falecido Avô. E se confirma a verdade das palavras do velho Mariano: eu teria residências, sim, mas casa seria aquela, única, indisputável. (UR, p. 29)

A diminuição da distância afetiva e a familiaridade da personagem com a sua terra natal também é expressa sob o signo da casa. Mariano reporta-se às lembranças da infância, ao observar a cozinha de Nyumba-Kaya:

E se refazia o eterno: na cozinha se afeiçoavam, sob gesto de mulher, o fogo e a água. Como nos céus, os deuses moldavam a chuva e o relâmpago. A cozinha me transporta para distantes doçuras. Como se, no embaciado dos seus vapores, se fabricasse não o alimento, mas o próprio tempo. Foi naquele chão que inventei brinquedo e rabisquei os meus primeiros desenhos. Não era apenas a casa que nos distinguia em Luar-do-Chão. A nossa cozinha nos diferenciava dos outros. Em toda a Ilha, as cozinhas ficam fora, no meio dos quintais, separadas da restante casa. Nós vivíamos ao modo europeu, cozinhando dentro, comendo fechados. (UR, p. 145)
A cozinha, cômodo de uso comum, local da partilha dos alimentos, ganha significado especial. Associada à "doçura" da infância, quando os elementos primordiais, o fogo e a água, eram mantidos sob o equilíbrio natural, a casa simboliza a estabilidade afetiva, os valores da intimidade, da proteção e da integração humana. A habitação da casa faz o ser convergir para o eu do passado. Emerge, então, a imagem da pessoa pelo devaneio da infância, revelando, a partir da profundidade de seu interior, seus valores, suas diferenças.

A dinâmica da imagem faz aparecer o ser tanto pela intimidade, com o recolhimento ao espaço interior, quanto pelo seu poder de expansão sobre o exterior. Nesse sentido, na medida em que à imensidão do mundo se sobrepõe a profundidade do espaço interior, a poética da casa pela dinâmica da memória propicia o aparecimento do eu pela atestação de suas capacidades no percurso do reconhecimento. Conferir ao objeto a poética do ato narrativo significa também realizar a abertura ao leitor para o preenchimento das imagens conforme contraste com os valores do seu universo cultural. Consoante Bachelard,

Nessa convivência com a espacialidade poética que vai da intimidade profunda à extensão indefinida, reunidas numa mesma expansão, sentimos brotar uma grandeza. Rilke disse: "Por todos os seres se desdobra o espaço único, espaço íntimo no mundo..." [...] Quando o espaço é um valor - e haverá maior valor que a intimidade? - ele cresce. O espaço valorizado é um verbo; em nós ou fora de nós, a grandeza nunca é um "objeto". Dar seu espaço poético a um objeto é dar-lhe mais espaço do que aquele que ele tem objetivamente, ou melhor dizendo, é seguir a expansão de seu espaço íntimo. (BACHELARD, 2008a, p. 206)

Durante o longo processo de transformação a que se submete Mariano perante as exigências do mundo, a imagem da casa da infância propicia o desvelamento da personagem pelo instante onírico do repouso. A casa "não é um simples cenário onde a memória reencontra suas imagens" (BACHELARD, 2003, p. 92), mas, porque a imaginação é posta em ação pela memória, passa a ser o desejado e perfeito espaço do refúgio. Nos seus estudos a respeito da imaginação material das substâncias terrestres, Bachelard observa que

A casa da lembrança, a casa natal, é construída sobre a cripta da casa onírica. Na cripta encontrase a raiz, o apego, a profundidade, o mergulho dos sonhos. Nós nos 'perdemos' nela. Há nela um infinito. Sonhamos com ela também como um desejo, como uma imagem que às vezes encontramos nos livros. Ao invés de sonhar com o que foi, sonhamos com o que deveria ter sido, com o que teria estabilizado para sempre nossos devaneios íntimos. (BACHELARD, 2003, p. 77; grifo do autor) 
O simbolismo da casa amplia-se pelas diversas perspectivas imaginárias propostas no romance. Perpassando a dialética narrativa que desvela o ser pelo movimento entre exterior e interior e anexa tempo e espaço por intermédio da prática da personagem que busca ser-no-mundo, a casa, arquétipo do enraizamento humano, materializa o drama existencial de Mariano pelas múltiplas realidades da imagem. Considerando que "o psiquismo humano formula-se primitivamente em imagens" (BACHELARD, 2008b, p. 04), a constituição da personagem se abre à competência da leitura.

Portanto, sem prescindir do diálogo com a história monumental, a figuração do ser que se erige pela personagem-memória torna-se o cerne da relação estabelecida com o leitor. Ao descentralizar o tempo pela projeção das distintas temporalidades com a imaginação de que é dotado o olhar que se volta para o passado pela memória e, assim, arma o futuro, a narrativa liberta os impulsos do sujeito histórico para a criação da própria vida. A alteridade que prevalece nessa relação com o tempo, tornando, sob os signos do mesmo e do outro, o ser estrangeiro de si mesmo no mundo, alimenta a expectativa para a projeção de novas e diferentes realidades.

\section{Referências}

BACHELARD, Gaston. A terra e os devaneios do repouso: ensaio sobre as imagens da intimidade. 2. ed. Tradução de Paulo Neves. São Paulo: Martins Fontes, 2003.

BACHELARD, Gaston. A poética do espaço. Tradução de Antonio de Pádua Danesi. São Paulo: Martins Fontes, 2008a.
BACHELARD, Gaston. A terra e os devaneios da vontade: ensaio sobre a imaginação das forças. 3. ed. Tradução de Maria Ermantina Galvão. São Paulo: Martins Fontes, 2008 b.

BORGES, Jorge Luis. História da eternidade. Lisboa: Quetzal Editores, 2012.

CHEVALIER, Jean. Diccionario de los símbolos. Barcelona: Editorial Herder, 1986.

COUTO, Mia. Um rio chamado tempo, uma casa chamada terra. São Paulo: Companhia das letras, 2003.

DELEUZE, Gilles. Proust e os signos. Tradução de Antonio Piquet e Roberto Machado. Rio de Janeiro: Forense Universitária, 2010.

GADAMER, Hans-George. O problema da consciência histórica. Tradução de Anselmo Freitas, Luísa M. Ferreira. Porto: Estratégias Criativas, 1998.

HAMBURGER, Käte. A lógica da criação literária. São Paulo: Perspectiva, 1986.

HEIDEGGER, Martin. Ser e tempo. Tradução, organização, nota prévia, anexos e notas: Fausto Castilho. São Paulo: Ed. da Unicamp; Rio de Janeiro: Vozes, 2012.

RICOEUR, Paul. Percurso do reconhecimento. São Paulo: Edições Loyola, 2006.

RICOEUR, Paul. Tempo e narrativa. Tradução de Claudia Berliner. São Paulo: WMF Martins Fontes, 2010. v. 1, 2, 3.

SAID, Edward. Fora de lugar: memórias. Tradução de José Geraldo Couto. São Paulo: Companhia das Letras, 2004.

Recebido: 17 de abril 2014 Aprovado: 26 de setembro 2014 Contato: ilsevivian@hotmail.com 